\title{
Developing of Entrepreneurial Spirit in the Era of Asean Economic Community in Vocational High School
}

\author{
Jahani \\ Doctoral Program, Human Resource Management, State University of Jakarta \\ J1. Rawamangun Muka, RT.11/RW.14, Rawamangun \\ Jakarta Timur, 13220, Indonesia \\ E-mail: jahani.nurhanifa@gmail.com \\ Hady Efendy (Corresponding Author) \\ Titan Mineral Utama \\ Graha Anabatic $10^{\text {th }}$ Floors, Scientia Boulevard Kav. U2 Summarecon \\ Tangerang 15811, Indonesia \\ E-mail: efendy_hady@yahoo.co.id
}

Received: August 14, 2017 Accepted: August 27, 2017 Published: September 12, 2017

doi:10.5296/ijld.v7i3.11702 URL: https://doi.org/10.5296/ijld.v7i3.11702

\begin{abstract}
The entrepreneurship vocational school program is based on national policy points in the field of education contained in the National Medium Term Development Plan (PRJMN) document 2015 to 2019. To implement the entrepreneurship Vocational High School (SMK) program as related to the achievement of national policy in the field of education, especially that leads to the formation of character with the formation of attitudes and entrepreneurship attitudes of participants Educate in the management of education is expected to be able to find a better management of education strategy so as to produce output of quality education both viewed from academic and non academic quality. To be a successful entrepreneur, the main requirement is to have an entrepreneurial spirit and character. The entrepreneurial spirit and
\end{abstract}




\section{Macrothink}

International Journal of Learning and Development

ISSN 2164-4063 2017, Vol. 7, No. 3

character are influenced by skill, ability, or competence. School or educational institution becomes a very strategic place to grow entrepreneurial talent. Facing the ASEAN Economic Community required human resources who are committed in entrepreneurs. So entrepreneurship education becomes one of the strategy effort in responding to the challenge. This article is descriptive analytic that is using the theories of experts to give an idea that the importance of entrepreneurship education in building entrepreneurship intentions of vocational students. So in the implementation of entrepreneurship education can be done through an integrated subjects as a force in the development of entrepreneurial interest. Building an intention in the entrepreneurship education process can be influenced by various factors such as internal factors, external and contextual. Therefore, to encourage the incidence of vocational students in entrepreneurship after graduation needs to get support from all parties, until the birth of intention that will be a reflection of the behavior of the real entrepreneur.

Keyword: ASEAN economic community, entrepreneurship, life skills, vocational high school 


\section{Introduction}

\subsection{Background}

The globalization that has occurred so far has given rise to changes in all fields. The organization's environment changes every time, so business organizations are required to always make changes and adapt to always win the competition. Free trade to be realized in 2010 and 2020 requires the availability of skilled and highly competent labor to compete in the labor market, both regional, national and international. Consequently, formal education institutions such as Senior High School (SMU), Vocational High School (SMK) are required to produce graduates who are ready to work, have attitude, entrepreneurial character and behavior and life skill to work in all fields according to the needs of industrial world.

The development of learning in the organization of vocational education should continue to be done by vocational education managers so that the quality of graduates is in line with the demands of the job market. The challenges of the work world with higher work competencies as technological advances and workplace dynamics require vocational education institutions to anticipate and cope with the changes taking advantage of existing capabilities. Vocational education institutions as potential employment providers should be able to utilize their resources and network of partnership resources with outsiders effectively.

Culture of innovation or development as a process involving management, professionals (lecturers/instructors) and the whole community of institutions including stakeholders can give birth to new ideas in the implementation of vocational education. Institutions with an innovative culture provide support to the management team in utilizing the capabilities of internal and external resources to improve the quality of graduates. Partnerships in the organization of vocational education between educational institutions and industry/workplace are the main characters of vocational education.

Facing the era of ASEAN economic community, it is necessary to have qualified human resources in Indonesia so as to compete with ASEAN countries. The government is very aware of this so that Indonesia's quality human resources must be achieved especially in the field of education. Therefore the Indonesia government seeks to improve the quality of national education by rolling out programs that are in line with the needs of today's society. One of the programs launched by the Indonesia government, in this case the Ministry of National Education is vocational High School of entrepreneurship program.

The entrepreneurship vocational school program is based on national policy points in the field of education contained in the 2015 National Medium Term Development Plan (PRJMN) document 2019. PRJMN 2015 to 2019 has set nine priority agendas, known as Nawacita, based entirely on the Trisakti ideology. Trisakti's ideology includes political sovereignty, economic self-reliance, and personality in culture. Nine priority agendas as Nawacita are: to bring the country back to protect the entire nation and to provide a sense of security to all citizens; Making governments always present by building a clean, effective, democratic, and reliable governance; Develop Indonesia from the periphery by strengthening the regions and villages within the framework of the unitary state; Strengthening the presence of the state in 
undertaking system reform and law enforcement that is free of corruption, dignity and trust; Improve the quality of human life of Indonesia; Increase people's productivity and competitiveness in international markets so that the Indonesian nation can move forward and rise with other Asian nations; Realizing economic independence by mobilizing the strategic sectors of the domestic economy; Revolutionize the character of the nation; As well as reinforcing diversity and strengthening Indonesia's social restoration.

To implement the entrepreneurship vocational program in the school (Vocational High School/SMK) as related to the achievement of national policy in the field of education, especially that leads to the formation of character with the formation of attitudes and entrepreneurial behavior of learners in the management of education is expected to be able to find a better education management strategy resulting in quality education output Both from academic and non academic quality. The academic quality is the quality of students related to the field of science, while the quality of non-academic is related to the independence to be able to open a business or own field work. In other words SMK graduates are expected to have entrepreneurial character and behavior. In line with that, the Directorate of Vocational Education gives special attention to the improvement of the quality of instructional subjects of workshop and Entrepreneurship in vocational high school in the implementation of the 2013 curriculum to foster the entrepreneurial spirit of the learners.

Vocational students as one of the agents of change are expected to play an important role in the future economic development. The hope becomes a reality if the educational institutions / schools do the process of transformation other than through the process of knowledge transfer but also the transfer of values of entrepreneurs in the vocational school so that they realize that entrepreneurship is not an alternative job. So on this occasion the educational unit needs to internalize the values of entrepreneurship and build entrepreneurship spirit intention through entrepreneurship education as well as integration into various subjects taught in school. This article is analytic descriptive by using the theories of experts on entrepreneurship education and entrepreneurial intentions then performed an analysis to find the point of effectiveness of entrepreneurship education in building entrepreneurial intentions in vocational high schools.

\subsection{Research Methods}

Research Approach in this article uses qualitative research approach. Qualitative research is a research procedure that produces descriptive data in the form of written or oral words based on the study of the literature. The reason the authors use qualitative methods because in doing research is expected to run naturally as well as obtain data that objective and depth. The problems discussed in this research is to know how the school effort in developing entrepreneurship spirit of vocational students.

\section{Literature Review}

The word entrepreneurship itself actually originated from the French language is 'entreprende' which means adventurers, creators, and business managers. According Suryana (2013) suggests that entrepreneurship is the creative and innovative performance used as the basis, 
tips and resources to 8 looking for opportunities to succeed. While Drucker (1994: 28) states that entrepreneurship refers more to the nature, character and traits attached to someone who has a strong willingness to realize innovative ideas into the real world of business and can develop it with a respite. Understanding of entrepreneurship by Joshep Schumpeter in Alma Buchari (2008: 21) that the entrepreneur is a person who break the existing economic system by introducing new goods and services, by creating new organizational forms or processing new raw materials. The terms entrepreneur and entrepreneur have the same meaning when viewed from various literature, and vice versa. But if reviewed more deeply there is also a difference from the term entrepreneur and entrepreneur, the entrepreneur is more focused on the object, there is an independent business. While the entrepreneur is more emphasis on the soul, the spirit is then applied in all aspects of life. In this study is meant by the entrepreneurial spirit is the desire of one's own in channeling the creativity that is owned so that can be used as land for income by building a new business independently.

In accordance with Government Regulation No. 19 of 2005, Article 26 paragraph 3 that the competency standards of graduates in the vocational secondary education unit (SMK) aims to improve intelligence, knowledge, personality, noble attitude, and skills for independent living and follow further education in accordance with the vocational. In the Regulation of the Minister of National Education No. 23 of 2007, on the Competency Standards of SMK Education Graduate Competencies, among others, master the competence of skills and entrepreneurship programs both to meet the demands of the world of work and to follow higher education in accordance with the vocational.

From the provisions of the above rules can be concluded that the SMK has a goal to graduate in the end ready to enter the employment field and continue education to a higher level. In the context of ready to enter the workplace is as a middle-level workforce to meet the needs of employment, as well as independently entrepreneurship so as to create employment.

The presence of ASEAN economic community is of great concern to all parties, both governments as policy makers, educational institutions as a producer of human resource, and the community as implementers on the agenda. It is a great hope for all of us to be able to participate in the global competition in the ASEAN economic community. The phenomenon that occurs today a lot of graduate SMK students who want to become an employee rather than being an entrepreneur. This condition illustrates that the mindset to become an entrepreneur among SMK graduates is still very small.

This shows that the government and the community have a role in facing these challenges, so that the role of education becomes a very strategic position as an effort in preparing qualified human resources by having various competencies and further orientation to become entrepreneurs.

The existence of entrepreneurial values cannot be separated from the contribution of education as well as interaction with the community environment. While entrepreneurial intentions can arise if there is an internal process in a person if the individual has personal and social awareness that is realized with an understanding of the ability of self, confident, self-motivated and have a fighting spirit in life. So that the role of the world of education 
including universities to always build and direct the ability and interest of SMK graduates to move and develop entrepreneurship, so that at least the current job field is no longer a crucial problem for every graduate.

Students of SMK as one agent of change that has an important role in the development of future economic growth. This expectation can occur when the educational institution can make a transformation other than the transfer of knowledge but also the transfer of values of entrepreneurs in students until students realize that entrepreneurship is not an alternative job but make a choice after graduation. So that the education unit needs to internalize the values of entrepreneurship and build the entrepreneurship spirit of vocational students through entrepreneurship education as well as integration into various subjects presented.

\section{Results and Discussion}

\subsection{Characteristic of Entrepreneurship in SMK}

Attitudes and entrepreneurial behaviors become very important in people's lives. Attitudes and entrepreneurial behavior will grow and develop, when the characteristics of the entrepreneurial self-have been strongly internalized in each student's personal. So with the internalization of entrepreneurial characteristics will give birth to attitudes and entrepreneurial behavior, which in turn will give birth to generations of entrepreneurs are more and more. This should continue to be a concern, because the Indonesian people are still very much in need of entrepreneurs to increase the prosperity of the people.

In the effort to create a strong entrepreneur, education (school) becomes one of the institutions that have a very important role. Schools are expected to transform the characteristics of entrepreneurship to their students. Vocational High School (SMK) has the main goal is to produce graduates who are ready to enter the work field, either independently or work on others. In the context of working independently, the graduates should be able to become entrepreneurs. In an effort to internalize entrepreneurial characteristic in SMK students, it must be created situations and conditions that accustom to think, behave and act as the characteristics of an entrepreneur. The form of habituation application of entrepreneurial characteristics in SMK can be done through:

\subsubsection{Teaching and Learning Activities}

Teaching and learning activities are two simultaneous, simultaneous and focusing activities that are shared. As a planned activity, learning has a permanent purpose, namely the occurrence of changes in students. Behavior change in students, in the context of teaching is clearly the product and effort of teachers through teaching activities. This teaching is a special activity undertaken by teachers to help and guide students to gain change and skills development, attitude, prestige and knowledge (Pupuh Fathurrohman \& Sobry Sutikno, 2007).

Teaching and learning attitudes in SMK, in terms of efforts to familiarize the application of entrepreneurial characteristics can be done through activities: 


\section{1). Entrepreneurial subjects}

The standard of competence or basic competence in entrepreneurship subjects must first be analyzed for its characteristics such as the opening of insight, attitude planting, technical briefing or briefing of entrepreneurship early experience. So that the main indicators in each basic competence should not be out of its nature. Further activities ranging from planning, implementation and assessment of learning should simultaneously refer to the main indicators that have been made.

The pattern of entrepreneurial learning by nature is done as follows:

a. Opening Insights is done through activities such as lectures, discussions, inviting successful vocational graduates, inviting entrepreneurs around the school to share their successes and failures or visit the company, through direct observation through apprenticeship or comparative studies.

b. Planting Attitude, done through habituation and courage to do something. Sometimes have to go through "pressure", "compulsion" in a positive sense, among others, by giving a deadline (deadline)

c. Technical Training, aimed at providing technical provisions and beneficial to the journey of the protégés, not the grandiose science. The strategy is done through guidance and practice.

d. Briefing on the initial experience, aimed at encouraging bold "stepping" learners, feeling the pleasure of success and learning from the bitterness of failure. The strategy can be done through practice.

\section{2). Integration into the subject}

What is meant by integrated entrepreneurship education in the learning process is the internalization of entrepreneurial values into learning so that the results obtained awareness of the importance of values, the formation of entrepreneurial character and the habituation of entrepreneurial values into the behavior of everyday learners through the process of learning Both inside and outside the classroom on all subjects. Basically learning activities, in addition to making learners master the targeted competence (material), are also designed and done to make learners recognize, aware / care, and internalize entrepreneurial values and make them behavioral. This step is done by integrating the values of entrepreneurship into learning in all subjects in school. This integration step can be done when delivering the material, through learning methods or through a scoring system.

In the integration of entrepreneurial values there are many values that can be instilled in the learner. If all the values of entrepreneurship should be invested with the same intensity on all subjects, then planting the value becomes very heavy. Therefore, the cultivation of entrepreneurship value is done gradually by choosing a number of principal values as a starting point for the planting of other values. Furthermore, these basic values are integrated in all subjects. Thus each subject focuses on the cultivation of certain fundamental values closest to the characteristics of the subject matter. The core values of entrepreneurship that are integrated into all subjects in the first step are 6 (six) principal values that are: independent, creative risk taker, leadership, orientation to action and hard work. 


\section{Macrothink

The integration of entrepreneurship education in the subjects is carried out from the planning, implementation, and evaluation of learning in all subjects. At the planning stage, syllabus and Learning Process Design (RPP) are designed so that the content and learning activities facilitate to integrate entrepreneurial values. How to construct a syllabus that integrates entrepreneurial values is done by adapting the existing syllabus by adding one column in the syllabus to accommodate the entrepreneurial values to be integrated. While the way RPP is integrated with entrepreneurial values is done by adapting existing RPP by adding to the material, learning steps or assessment with entrepreneurial values.

The principle of learning used in the development of entrepreneurship education seeks to enable learners to recognize and accept entrepreneurial values as their own and to be responsible for the decisions they make through the stages of knowing choices, assessing choices, determining stance, and then making a value according to self-belief. With this principle, learners learn through the process of thinking, acting, and doing. These three processes are intended to develop the ability of learners in conducting activities related to entrepreneurial values.

The integration of entrepreneurial values in syllabus and RPP can be done through the following steps:

- Assess Competency Standard (SK) and Competency Basic (KD) to determine whether entrepreneurial values are included.

- List the entrepreneurial values listed in the SKD and KD into the syllabus.

- Develop active learning steps that enable learners to have opportunities to integrate values and demonstrate in behavior.

- Incorporate active learning steps that integrate entrepreneurship values into RPP.

\section{3). Integrated Entrepreneurship Education in Extra Curricular Activities}

Extra-Curricular Activities are out-of-school educational activities and counseling services to assist the development of learners according to their needs, potentials, talents and interests through activities that are specifically organized by educators and / or education staff who are capable and authorized in the school / madrasah. The vision of extra-curricular activities is the development of potential, talent and interest optimally, as well as the growing independence and happiness of learners that are useful for themselves, families and communities. Extra-curricular missions are (1) providing a range of activities that learners can choose according to their needs, potential, talents and interests; (2) organizing activities that provide learners the opportunity to express themselves freely through independent and / or group activities.

\section{4). Entrepreneurship Education through Self Development}

Self-development is an out-of-school educational activity as an integral part of the school curriculum. Self-development activities are character building efforts including the entrepreneurial character and the personality of learners through counseling activities regarding personal and social issues, learning activities, and career development, and extra-curricular activities. 
Self-development is done in the form of activities development of competence and habits in the daily life of learners. Self-development aims to provide opportunities for learners to develop and express themselves in accordance with the needs, potential, talents, interests, conditions and development of learners, taking into account the condition of school.

Self-development specifically aims to support the education of learners in developing: talent, interest, creativity, competence, and habits in life, religious life skills, social skills, learning ability, insight and career planning, problem-solving skills, and independence. Self-development includes programmed and non-programmed activities. Programmed activities are planned specifically and followed by learners in accordance with their personal needs and conditions. Unplanned activities are carried out directly by educators and education personnel in the school / madrasah followed by all learners. In self-development programs, the planning and implementation of entrepreneurship education can be done through integrating into daily school activities such as 'business day' activities (bazaar, student work, etc.).

\section{5). Change of Entrepreneurship Learning from Theory to Practice}

In this way, entrepreneurial learning is directed at achieving three competencies that include entrepreneurship, concept and skill understanding, with greater weight on the achievement of life competence and skill compared with conceptual understanding. In the high school curriculum structure, on economic subjects there are several Basic Competencies that are directly related to the development of entrepreneurship education. These subjects are subjects that directly (explicitly) introduce entrepreneurial values, and to some extent make learners care and internalize those values. One example of entrepreneurial learning model that is able to grow entrepreneurial character and behavior can be done by establishing honesty canteen, etc.

\section{6). Integration of Entrepreneurship Education into Materials / Textbooks}

Materials / textbooks are the most influential learning component of what actually happens in the learning process. Many teachers teach by simply following the order of presentation and the learning activities (tasks) that have been designed by the author of the textbook, without making meaningful adaptations. Internalization of entrepreneurial values can be done into teaching materials in both material, task and evaluation.

\section{7). Integration of Entrepreneurship Education through in School Culture}

Culture / school culture is the atmosphere of school life where learners interact with each other, teachers with teachers, counselors with each other, administrative staff with each other, and among members of school community groups.

Development of values in entrepreneurship education in school cultures includes activities by principals, teachers, counselors, administrative staff when communicating with learners and using school facilities, such as honesty, responsibility, discipline, commitment and entrepreneurial culture in the school environment (All school residents do entrepreneurship activities in the school environment). 
8). Integration of Entrepreneurship Education through Local Content

These subjects provide opportunities for learners to develop the capabilities that are considered necessary by the region concerned. Therefore local content subjects should contain local cultural characteristics, skills, noble values of local culture and raised social and environmental issues that ultimately are able to equip learners with basic skills (life skills) as stock in life so as to create jobs. Examples of children who are in the environment around the coast, should be able to capture the local potential as an opportunity to manage into products that have added value, which then expected the child is able to sell in order to earn revenue.

The integration of entrepreneurship education in the local content, almost the same as the integration of integrated entrepreneurship education in the subjects carried out from the planning, implementation, and evaluation of learning in all subjects. At this stage of planning, the RPP is designed so that the content and learning activities of local content (MULOK) facilitate to integrate entrepreneurial values. How to develop an integrated RPP MULOK integrated with entrepreneurial values is done by adapting existing RPP MULOK by adding to the materials, learning steps or assessment with entrepreneurial values. The principle of learning used in the development of entrepreneurship education seeks to enable learners to recognize and accept entrepreneurial values as their own and to be responsible for the decisions they make through the stages of knowing choices, assessing choices, determining stance, and then making a value according to self-belief. With this principle learners learn through the process of thinking, acting, and doing. These three processes are intended to develop the ability of learners in conducting activities related to entrepreneurial values.

\section{9). Implementation of Industrial Work Practices}

As a form of implementation of the double system education (PSG) in SMK then implemented industrial work practices. Industrial work practice is a learning activity conducted in the business or industry, which is held at least four months during the education in SMK. At least there are at least three achievements that can be obtained in the implementation industrial work practice, namely the opening of insight, attitude planting and technical briefing entrepreneurship in a particular field. In order to achieve these three things, industrial work practice valuation activities should be aligned to the effort of opening insights, entrenched attitude and entrepreneurship technical briefing.

Assessment methods can be done through a portfolio of activity journals, presentations and interviews, as well as observations. Portfolio valuation method of activity journal is used to know technical knowledge. Presentation and interview methods for knowing technical knowledge and entrepreneurial insight. While the method of observation to know the technical skills and the entrepreneurship attitude.

\subsubsection{Application of the Values of Entrepreneurship Characteristics in the School Environment}

Characteristics of entrepreneurs can be grown through the application of entrepreneurial values in the school environment. Every citizen of the school starting from the leadership, teachers, employees and students must be consistent to the characteristics of entrepreneur into the 


\section{Macrothink}

behavior of everyday life. So that in the end students will be familiar with the pattern of life in accordance with the characteristics of entrepreneurship.

Efforts that can be done to foster entrepreneurial spirit through school culture that is by entering the values of entrepreneurial characteristics into the rules that apply in school. The rules should involve all the components of the school, and accommodate the interests of stakeholders for the betterment of the school, so that the regulation has undergone a material test of all the citizens of the school and recognized its existence. The rules include:

1). Student discipline

2). Code of ethics of teachers and employees

3). Other rules governing whoever is at that time in the school environment.

In an effort to apply the rules that apply in schools, it is necessary to do the following steps:

a. Socialization of regulations. This activity is carried out so that all the citizens of the school and stakeholders know that the school has applied the rules. The form of socialization can be through lectures, brochures, installation in strategic places in the school environment and others.

b. Implementation.

c. Supervision.

d. Giving punishment and rewards.

\subsubsection{The Practice of Entrepreneurship Activities}

The practice of entrepreneurship in schools is intended for students to have early experience in entrepreneurship. This can be done through among others:

\section{1). Involvement in Production Unit}

In the implementation of education in vocational schools there are also institutions called Production Units. Operation of Production Unit is the establishment of productive activity container in school which aims to help to increase production activity real to student, so that can produce according to world standard work and can inculcate entrepreneur spirit.

Production unit is a school business unit managed under the principal whose goal is expected to provide benefits to the school both to improve the welfare, motivation and procurement and maintenance of facilities using all facilities owned schools (Muniarti and Usman, 2009: 57). Production unit is a means of learning, entrepreneurship for students and teachers and provide operational support schools (Directorate of SMK Coaching, 2007: 1).

The type of production unit that is formed must be tailored to the program of expertise in SMK, the production unit is expected to support teachers and students in improving the ability as well as school welfare. The results of the production unit learning will have a positive impact on Teaching and Learning Activities (KBM) so as to create qualified graduates and on-demand employment.

The production unit in SMK is intended for business and learning fields, the main purpose of 
the production unit is to create a workforce that can be closer to specific job needs. The purpose of the production unit of each SMK will be accomplished if supported by the resources and responses of each school and the main purpose of the production unit in the guidance of the implementation of the unit of production, as follows: 1. Encourage Improvement of production-based learning for SMK. 2. Motivate SMK to build partnership in order to develop SMK production unit. 3. Increasing the imagery of SMK as a vocational education institution that carries out learning to produce a quality product. 4. Making SMK as a product outlet unit of production / teaching factory SMK in the vicinity.

Placing the Production Unit in the school, as the motor of entrepreneurship. Through this institution, starting from the level of concept planting, attitude planting, technical understanding and briefing of early experience of entrepreneurship can be done. As a production unit is a process of business activities undertaken in schools, is business-oriented (profit oriented) with the principals of schoolchildren, optimizing school and environmental resources, in various business units in accordance with proficiency in professionally managed.

\section{2). Co-curricular}

Co-curricular activity is a very tight and very supportive activities and assist in intra-curricular activities. Implementation outside of the intra-curricular activities aims to make students better understand the existing material, this activity in the form of assignment or homework associated with intra-curricular material. In the implementation of this co-curricular activity the teacher assigned to students in the form of homework related to entrepreneurship subjects, which is with the practice of making a product in entrepreneurial learning. The result of student practice become one of assessment requirement.

\section{3). Entrepreneurial Extracurricular}

Extracurricular activities are activities that are conducted outside the hours or outside the intra-curricular activities, the function of this activity is to channel or develop the ability of students in accordance with their interests and talents, expand knowledge, can socialize, fill the spare time and so forth. In the implementation there are things that must be considered in order to be implemented properly, including: 1. The implementation of activities should be beneficial for students both present and future 2. Implementation not interfere with intra-curricular learning or do not burden the students 3. Activities undertaken should benefit the environment, nature, industry and the business world.

Extracurricular entrepreneurial activities are directed to inculcate attitudes, provide technical briefing and provide entrepreneurial experience. The stages in the activities of extracurricular entrepreneurship are as follows:

- Exploring (practicing digging opportunities)

- Planning (plan the work system)

- Doing (innovation practice)

- Communicating (communication practice)

- Reflecting (evaluation and reflection practice) 
3.2 The Building Entrepreneurial Intentions of Vocational School Students through Entrepreneurship Education

Entrepreneurship education has an important role in building the willingness to entrepreneurship, as an entrepreneurship transfer activity for each individual to build a business does not hesitate to take advantage of business opportunities and more sensitive to take advantage of business opportunities that exist in it. Through entrepreneurship education, vocational school students will consider all business activities that they will do well. Entrepreneurship education within the vocational school environment will form entrepreneurs or businessmen who are strong and tough and ready to face the challenges they will face. The size of the risk in business is well considered and performs all entrepreneurial activities based on the instructions they know without any hesitation.

The influence of education on the development of entrepreneurial spirit is actually different from other external influences. In general, the social environmental influence of the community is more passive, in the sense that the environment does not provide a pressure on the individual, the environment only provides opportunities and opportunities as a place to develop themselves. The result of research stated that the main factor that need attention is the attitude of self-employment and self-efficacy by providing the provision of attitude development in responding to the existing opportunity and tolerate the risk in the business (Ranto \& Akademi 2016). Self-efficacy can be improved by providing knowledge and skills of entrepreneurship. In addition, the results of research can also contribute to the world of education, especially entrepreneurship education to pay attention to entrepreneurial attitudes and self-efficacy as an internal factor or personal. The pattern of entrepreneurship education provided to vocational school students should have an internalization effort on the value of confidence as well as confidence, dependency, individuality, and optimism as an effort to build innovative and creative souls in responding to opportunities, creating opportunities and entrepreneurial skills and knowledge such as establishing business and manage the business.

Each vocational school student can take an opportunity or opportunity for existing entrepreneurship, and it depends on the nature of each learner to take advantage of opportunities and opportunities. This is different from education, especially education related to entrepreneurship. Education is run with full awareness, has specific goals, targets, and objectives and is given systematically to develop potential entrepreneurial potential (Wibowo, 2012). The only struggle or way to manifest a person who has morale, attitude, and entrepreneurial skills is through education (Wasty, 2002). Through education in schools, it is hoped that individual insights of vocational school students become more confident, able to choose and make the right decisions, increase creativity and innovation, foster moral, character, intellectual, and other human resource quality improvement so that eventually able to become independent student. Education also serves to shape the personality of vocational school students become more powerful and resistant to problems encountered. A strong vocational student's personality is one of the underlying capital of an entrepreneur. To establish the desired quality element of the vocational school's student resources takes a long time, even life-long education concepts require participation from various parties, not just schools. So that with various efforts is able to create Entrepreneur Intentions to every student of vocational school. 


\subsection{The Concept of Entrepreneurship and Entrepreneurship Characters}

Prasetyo (2009) argued that entrepreneurship is essentially the nature, character and character of someone who has the will to realize innovative ideas into the real world creatively. The term entrepreneurship can be defined as "the backbone of economy", which is the nerve center of the economy or the control of a nation's economy. Epistemologically, entrepreneurship is a value necessary to start a business or a process in working on something new and different. Entrepreneurship is the application of creativity and innovation to solve problems and efforts to take advantage of the opportunities faced daily. Entrepreneurship is a blend of creativity, innovation and courage at risk by hard work to shape and nurture new ventures.

According to Sudrajat (2011), until now the concept of entrepreneurship is still growing. Entrepreneurship is an attitude, a soul and the ability to create something new that is very valuable and useful to itself and others. Entrepreneurship is a mental attitude and soul that is always active or creative empower, create, work and understated and strive in order to increase revenue in business activities. The entrepreneurial expert Peter F. Drucker (quoted in Jayadi, 2010), defines entrepreneurship as the ability to create something new and different. In this sense, entrepreneurship is closely related to the ability of creation and innovation. The ability of the entrepreneur is to create something new or different from others, or be able to create something different from pre-existing ones.

Sudrajat (2011) explains that someone who has an entrepreneurial character is always not satisfied with what he has achieved. Entrepreneurs are skilled people who take advantage of opportunities in developing their business with the aim to improve their lives. Norman M. Scarborough and Thomas W. Zimmerer (quoted in Sudrajat, 2011) say "An entrepreneur is one who creates a new business in the face of risk and uncertainty for the purpose of achieving profit and growth by identifying the opportunities and assembling the necessary resources to capitalize on issues ". Entrepreneurs are people who have the ability to see and assess business opportunities; collect the resources needed to take appropriate action, take advantage and possess the nature, character and willingness to realize innovative ideas into the real world creatively in order to achieve success / increase revenue. In essence, an entrepreneur is a person who has the character of entrepreneurship and apply the nature of entrepreneurship in his life. In other words, entrepreneurs are people who have a high creativity and innovative spirit in their lives.

Of the several concepts above shows as if entrepreneurship is identical with the ability of entrepreneurs in the business world (business). Whereas according to Soeparman Soemahamidjaja (quoted in Sudrajat, 2011), in reality entrepreneurship is not always identical with the entrepreneurial character alone, because entrepreneurial character may also be owned by a non-entrepreneur. Entrepreneurship covers all aspects of work, both private and government employees. Entrepreneurs are those who make creative and innovative efforts by developing ideas, and mixing resources to find opportunities and life preparation.

Entrepreneurship (entrepreneurship) arises when an individual dares to develop his new efforts and ideas. The entrepreneurship process includes all functions, activities and actions related to the acquisition of opportunities and the creation of business organizations. The essence of 
entrepreneurship is creating added value in the market through a process of combining resources in new and different ways to compete (Sudrajat, 2011). The added value can be created through the following ways: 1). Developing new technology; 2). Discovering new knowledge; 3). Improving existing products; and 4). Finding different ways of providing more goods and services with fewer resources.

Although among the experts there is more emphasis on entrepreneurship in the role of small entrepreneurs, but in fact the entrepreneurial character is also owned by people who work outside of entrepreneurship. The entrepreneurial character is present in everyone who loves change, renewal, progress and challenge, whatever the profession. Thus according to Sudrajat (2011), there are six essentialities of entrepreneurship, namely:

1) Entrepreneurship is a value embodied in behaviors that are used as resources, driving forces, goals, strategies, tips, processes and business outcomes.

2) Entrepreneurship is a value needed to start a business and grow a business.

3) Entrepreneurship is a process of doing something new (creative) and different.

4) Entrepreneurship is the ability to create something new and different.

5) Entrepreneurship is a process of applying creativity and innovation in solving problems and finding opportunities to improve business life.

6) Entrepreneurship is an effort to create added value by combining resources through new and different ways to win the competition.

Based on the six opinions above, it can be concluded that entrepreneurship is the values that shape the character and behavior of someone who is always creative empowered, creating, working and understated and trying in order to increase revenue in business activities. Mulyani, et al (2010) provides an explanation of 6 (six) characteristics of entrepreneurial character, namely:

1) Confident, that is work full of confidence and not dependence in doing the job.

2) Oriented to tasks and outcomes, which meet the need for achievement, job orientation in the form of profit, diligent and steadfast, and has a determination of hard work.

3) Dare to take risks, which are brave and able to take on work risks and like challenging jobs.

4) Spiritual leadership, which is acting as a leader who is open to suggestions and criticism, and easy to get along and work with others.

5) Thinking toward the outcomes (benefits), that is creative and innovative; Tenacious in carrying out the work; has many resources; and versatile and knowledgeable.

6) Authenticity, which is thinking of looking ahead and perspective.

So, to be a successful entrepreneur, according to Sudrajat (2011) the main requirement that must be owned is to have entrepreneurial spirit and character. The entrepreneurial spirit and character are influenced by skill, ability, or competence. Competence itself is determined by knowledge and business experience. As has been pointed out above, that an entrepreneur is someone who has a certain soul and ability in creating and innovating. He is someone who has the ability to create something new and different (ability to create the new and different) or creative and innovative abilities. Such creative and innovative skills are reflected in the ability and willingness to start up, the ability to work on something new (creative), the willingness and 
ability to seek opportunities, the ability and the courage to bear the risk (risk bearing) And the ability to develop ideas and gather resources.

Today, an entrepreneur is not enough just to have the ability to create something different, creative, and innovative. However, an entrepreneur should be able to become a characteristic entrepreneur. The character in question is a healthy character that is in accordance with the culture and wisdom of the people of Indonesia through the concept of Characterpreneurship. The purpose of doing business or entrepreneurship is not just looking for luck alone, but also the person must be character. Characterpreneurship adheres to the value or ethics of business, anti-corruption, defense of domestic products, create jobs and certainly provide a blessing for the community.

Here are the principles of anti-corruption that must be upheld by entrepreneurs, that are:

a. Accountability. Accountability refers to the suitability between rules and work execution. All institutions are accountable for their performance according to the rules of the game, both in the form of convention (de facto) and the constitution (de jure), both at the cultural level (individuals with individuals) and at the institutional level. Accountability must be measurable and accountable through reporting mechanisms and accountability for the implementation of all activities.

b. Transparency. Transparency is a principle that requires all policy processes to be carried out openly, so that any form of deviation can be known by the public. Transparency becomes the entrance and control for the entire business process. In its simplest form, transparency refers to openness and honesty to uphold each other's beliefs.

c. Justice. The principle of justice is intended to prevent the occurrence of manipulation (mismatch) in budgeting, whether in the form of mark-ups or other irregularities. There are five steps to upholding justice: (1) Comprehensive and disciplined, considering the whole aspect, continuity, consistent principle, loading principle, and unlimited expenses. (2) Flexibility, namely the existence of policies for efficiency and effectiveness. (3) Predictable, i.e. provision in planning on the basis of value for money and avoid deficit in the current budget year. Predictable budgets are a reflection of the principle of fairness in the development planning process. (4) Honesty, namely the existence of a predictor of intentional acceptance or expenditure, derived from technical and political considerations. Honesty is a central part of the principle of justice.

Furthermore, it is no less important to become entrepreneurs who are characterized by pro products in the country or increase the use of domestic products. The nation will never advance, if its generation will not care. The nation will not be big if its generation has no creativity, and this nation will not grow if its generation is still dependent on foreign products. Time for Indonesia to rise. That is the ideals of the younger generation when chanting reforms. The reform age has been running for 10 years, but we are not yet elongated from the economic problem. The problem is, because we are less competitive and we ourselves still love overseas products. For that, let's start loving the domestic product.

No doubt also use the goods outside can be limited to prestige and to say cool, although not yet certain that the goods used have good quality and guaranteed quality. For Levis brand 
jeans, Indonesia has to pay for its brand use here. Though the pants were made in the country. Production and materials also from within the country. For that the whole community is urged not to doubt in using the product "made in Indonesia". Therefore it is deemed necessary to encourage entrepreneurs with the character to continue to increase the use of domestic products in the procurement of goods or services, thus encouraging entrepreneurs to increase their production and accelerate the development of domestic and export markets.

So it can be concluded that becoming a character entrepreneur is very important, because it not only brings success for the entrepreneur itself. But also able to bring success for Indonesia. Wibowo (2010) says that character is the key to individual success. From an American study, $90 \%$ of dismissal cases are caused by bad behavior such as irresponsibility, dishonesty, and bad interpersonal relationships.

\subsection{Understanding Character Education of Entrepreneurship}

According to Wibowo (2011), character is the values of human behavior associated with God Almighty, self, fellow human, environment and nationality embodied in thoughts, attitudes, feelings, words and deeds based on religious norms, law, Manners, culture and customs. For Indonesia today, character education also means making a genuine, systematic and sustained effort to awaken and strengthen the awareness and confidence of all Indonesians that there will be no better future without building and strengthening the character of the Indonesian people. In other words, there is no better future that can be realized without honesty, without increasing self-discipline, without persistence, without high learning spirit, without developing a sense of responsibility, without cultivating unity in the midst of diversity, without the spirit of contributing Progress together, and without confidence and optimism.

Ferdian (2011) suggests that characteristic entrepreneurship education is a novelty now even though it is not something new. The cultivation of values as a characteristic of a person has been going on since time immemorial. However, along with the changing times, it seems to require a re-enforcement of these values into a container of educational activities in every teaching. The cultivation of these values is embedded into the learning implementation plan with the intention of achieving a character that has so far faded.

Each subject has its own values that will be implanted in the students. This is due to the primacy of focus of each maple which certainly has different characteristics. The distribution of the main values in each subject can be seen as follows:

1) Religious education

The main values are: religious, honest, polite, discipline, responsibility, love science, curious, confident, respect diversity, obey rules, social, healthy lifestyle, aware of rights and obligations, hard work, and fair.

2) Civic education

The main values embedded include: nationalist, obedient to social rules, democratic, honest, respect diversity, aware of the rights and obligations of self and others.

3) Indonesian Language

The main values embedded include: logical thinking, critical, creative and innovative, 


\section{Macrothink}

confident, responsible, curious, polite, nationalist.

4) Social Sciences

The main values invested include: nationalist, respect diversity, logical thinking, critical, creative, innovative, social and environmental concerns, entrepreneurial, honest, and hard work.

5) Natural Sciences

The main values invested include: curious, logical, critical, creative, and innovative, honest, healthy lifestyle, self-reliant, respectful, disciplined, independent, responsible, caring, and science-loving.

6) English

The main values embedded include: appreciate diversity, courteous, confident, independent, cooperate, obedient to social rules.

7) Art and culture

The main values embedded include: respect for diversity, nationalism, and respect for the work of others, willing, honest, disciplined, and democratic.

8) Physical education, Sports and the Arts

The main values invested include: healthy lifestyle, hard work, discipline, honest, confident, independent, respect the work and achievements of others.

9) Skills / workshops

The main values invested include: logical thinking, critical, creative, and innovative, independent, responsible, and appreciative of the work of others.

10) Local content

The main values embedded include: respect for togetherness, respect for the work of others, national, caring.

Each of these key values can be incorporated into learning from exploration, elaboration, to confirmation activities. The exploration is an early attempt to build knowledge through increased understanding of a phenomenon. The strategies used extend and deepen knowledge by implementing active learning strategies. The explorative learning approach not only focuses on how to transfer science, understanding, and interpretation, but must be balanced with the quality improvement of teaching materials. Information is not only compiled by the teacher. There needs to be student involvement to expand, deepen, or compile information on its initiative. In this case students compile and validate information as input for learning activities.

The application of the main values is included in the confirmation activities by way of (Ferdian, 2011):

1) Provide positive feedback and reinforcement in the form of oral, written, gestures, and gifts to the success of learners (examples of values invested: mutual respect, confidence, polite, critical, and logical).

2) Confirm the results of exploration and elaboration of learners through various sources (examples of embedded values: confident, logical, and critical).

3) Facilitating learners to reflect on the learning experience they have done (e.g. embedded values: understanding the advantages and disadvantages). 
4) Facilitate learners to further / deep / wide gain on the learning of knowledge, skill, and attitude. The function of teacher are:

a. Serves as a resource and facilitator in answering questions of learners who are facing difficulties, using standard and correct language (e.g. embedded values: caring, polite).

b. Helping to solve the problem (e.g. embedded value: caring).

c. Provide guidance so that learners can check the results of exploration (example value embedded: critical).

d. Giving information to explore further (example value embedded: love of science).

e. Provide motivation to learners who are less or have not actively participated (e.g. values invested: caring, confident).

Cultivation of this value that will be expected to make the students become entrepreneurial candidates who are more character. Suherman (2011) said that the entrepreneurship education program characterized in schools aims to:

1) Strengthening the implementation of the curriculum of the existing curriculum in each educational unit from early childhood to senior secondary education and non-formal education by strengthening learning methods and integrating entrepreneurship education.

2) Assessing content standards and competency standards graduates and curriculum from early childhood to senior secondary education and non-formal education in mapping the scope of graduate competencies related to entrepreneurship education.

3) Formulate the design of entrepreneurship education in every educational unit ranging from early childhood education to senior secondary education and non-formal education.

The targets of entrepreneurship education programs are characterized by educational units ranging from early childhood to senior high school and non-formal. Through this program is expected to graduate learners on all types and levels of education. Then the other school residents have the spirit and entrepreneurial spirit of the character. Furthermore, Mulyani, et al (2010) explained that entrepreneurship education should be able to change the mindset of the learners. Entrepreneurship education will encourage students and students to begin to recognize and open a business or entrepreneurship. The mindset that is always oriented to be employee turned back to be oriented to find employees. Thus entrepreneurship can be taught through the cultivation of entrepreneurial values that will shape the character and behavior for entrepreneurship so that learners will be independent in working or self-supporting business.

Entrepreneurship education will provide opportunities for growth and development of potential creativity and innovation of children. Entrepreneurial values will be the characteristics of learners that can be used in socializing and interacting with the environment. In the end, individuals who have creative, innovative, responsible, disciplined and consistent character will be able to contribute in solving the problems of Indonesian human resources. It is no exaggeration to say that entrepreneurship education is socio-psychologically oriented. Entrepreneurship education will reduce the mindset of learners about the goals and orientation of following education to become a civil servant. Entrepreneurship education also prepares learners to have an entrepreneurial attitude and is able to develop all of his potential to face his future with all his problems. 


\subsection{Assessment of Entrepreneurship Education in SMK}

Assessment is an ongoing process for detecting the strengths and weaknesses of learners in aspects of character, skills, and knowledge. Each stage of the learning process can occur the assessment process. For example, the exploratory stages of learners are assessed about the ability to design data capture tools, the ability to see opportunities, draw conclusions, and when action can be seen about cooperation, timeliness, material management skills. At the communication stage is assessed the ability to explain about the subject matter, the ability persuasive, and the attitude of respecting the other person. Some models of entrepreneurship education, the assessment can be integrated in all subjects, embodied in life skills activities, local content / extracurricular, and attached to the subjects. The assessment of entrepreneurship education is based on rubrics that cover aspects of understanding (cognitive), affective aspects and organizing skills.

\section{Conclusion}

Implementation of entrepreneurship education in vocational high schools can be done through one subject or integrated in other subjects. Thus the implementation of the economic effectiveness of the state is always associated with the educational world that has a strategic position in preparing qualified human resources with the strength to face the challenges and risks. Such strengths are like heads or thoughts, hearts or feelings, hand or skill, health or health. Besides, individuals have entrepreneurial values as well as self-confidence, initiative, leader, brave, originality, creativity, innovative, as good business ethics and norms, and is responsible and has self-discipline. Entrepreneurial intention is the first step of a process of establishing a business, so it becomes the material consideration of various factors that can influence the birth of a strong intention such as external factors (family, business, physical, social), internal factors (attitude, And ability), and contextual factors (entrepreneurship and experience education). Consequently with the birth of a sincere intention in every work to be carried out even believed that a behavior-related intention proved to be a reflection of the actual behavior. In the end, the vocational education institution remains a very important position in the internalization of entrepreneurship values to vocational high school students, so as to become the initial provision for every student in facing the society of the Asian economy.

The success of entrepreneurship programs in vocational high schools (SMK) is strongly influenced by the quality of learning subjects and entrepreneurship. Entrepreneurship in SMK is a program to recognize the concept of entrepreneurship, business development exercises, gain practical experience of entrepreneurship, foster entrepreneurship interest and develop entrepreneurship potential on student psyche. Therefore, entrepreneurship programs in vocational schools should be an alternative in preparing SMK graduates who are able to apply and manage business opportunities and able to adjust themselves to succeed in social life and have the ability to face competition in the era of ASEAN and global economic community.

Entrepreneurship program in Vocational School is a real effort in order to cultivate entrepreneurship value and improve the quality of learning of the subject of entrepreneurship and entrepreneurship in SMK with the aim that students have entrepreneurial character, understand the concept of entrepreneurship, able to see opportunities, get direct experience of 
entrepreneurship and the establishment of school environment as environment Learning with an entrepreneurial perspective. Therefore, in order for entrepreneurship programs in SMK to be implemented effectively and efficiently and achieve optimal results, it is necessary to have commitment from all related parties to jointly strive for the smoothness and success of the whole process of learning Entrepreneurship in accordance with the duties, functions and authority of each Agencies.

Through this entrepreneurship program, it is expected that the teachers of entrepreneurship subject, practical subject and related parties know about the mechanisms and procedures for the implementation of entrepreneurship programs in the aspects of processing and practical aspects on the subjects of workshop and entrepreneurship in vocational high school (SMK).

\section{References}

Alma, B. (2008). Keentrepreneuran untuk mahasiswa dan umum. Bandung: Alfabeta.

Ferdian. E. P. (2011). Karakteristik Kewirausahaan Pada Mahasiswa Manajemen 2011 Universitas Katolik Soegijapranata. Skripsi. Universitas Katolik Soegijapranata. Semarang.

Kementerian Pendidikan Nasional. (2010). Pengembangan Pendidikan Kewirausahaan. Bahan PelatihanPenguatan Metodologi Pembelajaran Berdasarkan Nilai-Nilai Budaya untuk Membentuk Daya Saingdan Karakter Bangsa. Jakarta: Badan Penelitian dan Pengembangan Pusat Kurikulum.

Kementerian Pendidikan Nasional. Badan Penelitian dan Pengembangan, Pusat Kurikulum, (2010). Pengembangan Pendidikan Kewirausahaan. Jakarta.

Mulyani, Endang dkk. (2010). Pengembangan Pendidikan Kewirausahaan. Jakarta. Badan Pelatihan dan Pengembangan Pusat Kurikulum.

Murniati, AR \& Usman, Nasir. (2009). Implementasi Manajemen Stratejik Dalam Pemberdayaan Sekolah Manajemen Kejuruan, Bandung: Citapustaka Media Perintis.

Peraturan Menteri Pendidikan Nasional Nomor 23 tahun (2007). Tentang Standar Kompetensi Lulusan.

Peraturan Pemerintah Nomor 19 tahun. (2005). tentang Standar Nasional Pendidikan. Lembaran Negara Republik Indonesia.

Prasetyo, I. (2009). Membangun Karakter Wirausaha Melalui Pendidikan berbasis Nilai dalam Program Pendidikan Non Formal. Jurnal PNFI, 1(1), 1-12.

Pupuh, F., \& Sobry, S. (2007). Strategi Belajar Mengajar Melalui Penanaman Konsep Umum dan Konsep Islam (pp. 156). PT. Refika Aditama. Bandung.

Ranto, D. W. P., \& Akademi, M. A. YPK. (2016). Membangun Perilaku Entrepreneur Pada Mahasiswa Melalui Entrepreneurship Education. JBMA, III(1)

Sudrajat, Akhmad. 2011. Konsep Kewirausahaan dan Pendidikan Kewirausahaan di Sekolah. Retrieved June 29, 2016, from http://akhmadsudrajat.wordpress.com/2011/06/29/konsep- 
kewirausahaandan-pendidikan-kewirausahaan/

Suherman. (2011). Pendidikan Kewirausaahaan Membentuk Karakter Bangsa. Retrieved 21 August, 2017, from www.radarlampung.go.id

Suryana, (2013). Kewirausahaan: Kiat dan Proses Menuju Sukses (4th, ed.). Jakarta: Salemba Empat.

Wasty, S. (2002). Pendidikan Wiraswasta (P. 78). Jakarta: Bumi Aksara. 2002.

Wibowo, M. (2012). Pembelajaran kewirausahaan dan minat wirausaha lulusan SMK.Eksplanasi 6.2 .

Zimmerer, T. W., Scarborough, N. M., \& Wilson, D. (2008). Essentials of Entrepreneurship and Small Business Management ( 5 th ed.), by Pearson Education, Inc., Upper Saddle River, New Jersey, USA.

\section{Copyright Disclaimer}

Copyright for this article is retained by the author(s), with first publication rights granted to the journal.

This is an open-access article distributed under the terms and conditions of the Creative Commons Attribution license (http://creativecommons.org/licenses/by/4.0/). 